\title{
AIRCRAFT GAS TURBINE ENGINE TESTING
}

\author{
Stanislav FÁBRY*, Miroslav SPODNIAK, Peter GAŠPAROVIČ, Peter KOŠČÁK \\ Technical University of Košice, Faculty of Aeronautics, Košice, Slovak Republic \\ *Corresponding author. E-mail: stanislav.fabry@tuke.sk
}

\begin{abstract}
The paper deals with testing of aircraft gas turbine engines. The main goal of the research is to propose and design testing sequence for a new or rebuilt engine. All factors and circumstances are described, including surroundings of the engine under test. Prerequisite knowledge is introduced, including the theory of testing, description of test beds, the methods of measurement of engine parameters and special factors that affect engine performance. Some examples of real testing facilities are mentioned. The result of the work is a proposal of test cycle, that can be modified according to engine purpose and specification.
\end{abstract}

Keywords: engine test; test bed; test cycle

\section{INTRODUCTION}

The development of an aircraft engine can be proceeded in two ways. When it is a completely new engine, its parts and modules are designed. Then the performance, strength and durability of parts and modules is tested. These properties used to be tested at various laboratories and workplaces. When the entire engine is completed, the final result of the development can be verified.

When existing type of engine is upgraded, changed components have to be tested individually and then the completed engine undergoes testing procedure.

Engine performance and safety is proven by a certification process. Engine tests must demonstrate its parameters. The organization and solution of the engine testing is closely related to knowledge of the engine design and the principles of the work of individual subsystems. Several specialised testing engineers are required, all of them skilled in aeronautical applications. Important part of testing procedure is recording of signals. Avionic specialists are needed for preparation of measurement equipment. The result of engine testing project is a collective work.

This research deals with factors influencing the testing of aircraft gas turbine engine (AGTE). In order to describe it sufficiently, it is needed at first to deal with engine testing facilities. Then it can be understood, how the accurate parameters of engine can be obtained during the test. Collecting testing facility properties and specifics, its advantages and disadvantages can be found out and summarized.

\section{THE PURPOSE OF ENGINE TESTING}

Strict requirements on AGTE ensure the safety and performance. The requirements continuously increase due to market growth. There are requirements for the structural and technological properties, operational economy and reliability of all parts of the engine.

Several purposes of testing aircraft engines and their parts and aggregates, either during a development or during a mass production, ensure achieving the goals as follows:

- control and verification of functions of engine and its parts,

- verification of calculated and prescribed engine parameters and characteristics,

- verification of strength-dynamic properties of engine,

- verification of engine reliability and durability. 
In sum, these goals ensure initial or continued airworthiness of engine. Its additional properties ensure high performance. The thrust of power unit and the fuel consumption seems to be the next important parameters. Testing of engine is also good occasion to find-out and optimise these parameters.

\section{TYPES OF TESTS}

Tests of AGTE can be evaluated from several qualitatively different aspects and classified into the following groups.

By the purpose and aim:

- research tests,

- development tests,

- certification (type) tests,

- tests after finalization of engine and after overhaul of engine.

According to engine assembly:

- testing of aggregates and devices,

- testing engine parts and components (modules),

- complete engine tests,

- testing of complete propulsion units and systems (engine with corresponding installations, housing and propeller-driven turboprop engine).

According to external test conditions:

- tests in normal ground conditions at the ground test facility,

- tests in elevated altitude conditions at ground test facility,

- in-flight tests.

Depending on the nature of the issues and features being monitored:

- thermodynamic tests,

- strength-dynamic tests,

- tests for engine design,

- tests for engine regulation and control.

\section{TYPES OF ENGINE TEST BEDS}

Tests are carried out in test beds and test cells that allow accurate measurement of environmental parameters and engine parameters. Individual test results may be compared to results from another test facility, to verify the accuracy or suitability of the test bed.

The layout and design of the test bed affects engine test conditions. Outdoor sea level test bed, indoor sea level test bed and flying test beds are used. Devices installed on engines for testing (output and exhaust nozzles, noise attenuators, etc.) may affect engine parameters and thereby performance [2]. They must be the same, when correlation tests are made.

\subsection{Outdoor Sea Level Test Bed}

The scheme of this kind of test bed is illustrated in Fig. 1. It is situated in open air area. The stand basically consists of frame (cradle) supporting an engine and providing the thrust measurements. The effects of cross wind on input air conditions are supressed by a large mesh screen that is fitted around the engine inlet. The area surrounding the test bed is free of the obstructions to the air flow, to ensure 
the validity of the thrust and the air flow readings. This is the most precise thrust test bed, because in the indoor test beds the thrust and the air flow measurements are negatively influenced by the effect of sidewalls on flow field.

Outdoor test beds are sited remotely from living areas and places of human activities, to minimize the environmental disturbance by produced noise. Due to the logistic difficulties and the impact of adverse weather conditions, indoor testing is preferred in most cases, with the thrust measurements calibrated (correlated) to the condition of outdoor facilities [3].



Figure 1 Outdoor sea level test bed [3]

\subsection{Indoor Sea Level Test Bed}

An indoor test bed is schematically shown in Fig. 2. Because it is enclosed by a building, it is called the test cell. It has similar engine arrangement to that in Fig. 1, however some details have to be added when the engine is mounted indoors. The air flow path to the engine is crucial, because it is highly restricted by available area. Anyway, the disturbance must be known and minimised. It is necessary to compare indoor measurement results with outdoor results of the same, or very similar engine. What is "very simillar" is stated using correlation tests in both facilities.

The test cell equipment, called detuner, is the tubular outlet of the test section. Gas from the engine output nozzle enters the detuner, which guides it out of the test cell and provides sound attenuation. For a given engine, the measured thrust is decreased up to $10 \%$ in comparison with the value recorded at outdoor test bed. This is due to unstable static pressure effects, acting on the engine, its equipment and the cradle, caused by the air streaming within the cell, passing by all above mentioned parts and test section walls. The air is entrained into the detuner by the ejecting effect of the output engine gas. It prevents hot gas re-ingestion and also cools the detuner.

At some engine regimes there can occur a rematch due to the air static pressure distribution at the nozzle exit. Anyway, the indoor test cell gives useful all-weather availability. Unless it is used for simple functional test, it should be calibrated against outdoor test bed, to determine the effects of the static pressure field and rematch [3]. 


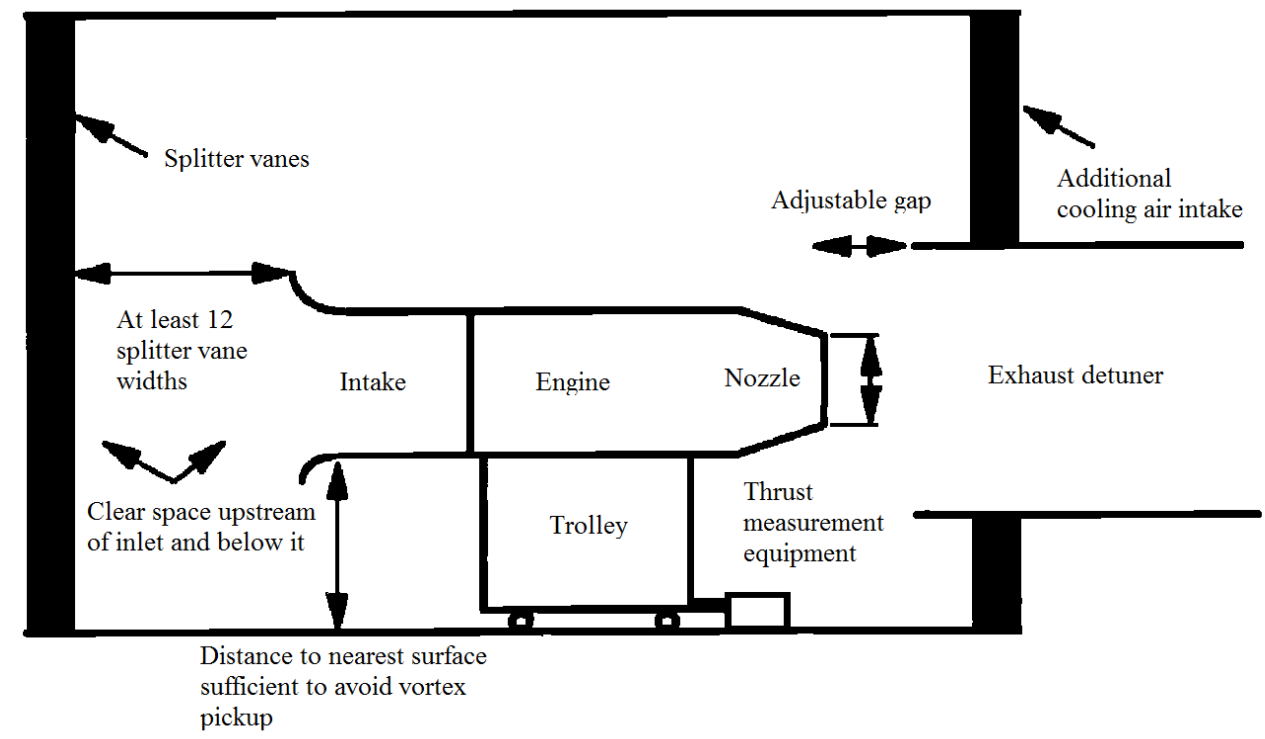

Figure 2 Indoor sea level test bed [3]

\subsection{Flying Test Bed}

A flying test bed is used for testing of power unit in real condition. Usually a four engine aircraft is adapted to mount a single, new development engine at one position. The advantages are as follows:

- better simulation of effects such as plane and structure loads and inlet distortion,

- low budget.

There are no direct measurements of the thrust and the mass flow. These must be calculated as follows:

- propelling nozzle thrust coefficient and capacity are obtained from rig and engine tests,

- nozzle entry total pressure and temperature are measured directly, with sufficiently covered sensors to obtain valid average data,

- mass flow can be calculated using exit velocity,

- fuel flow is measured [3].

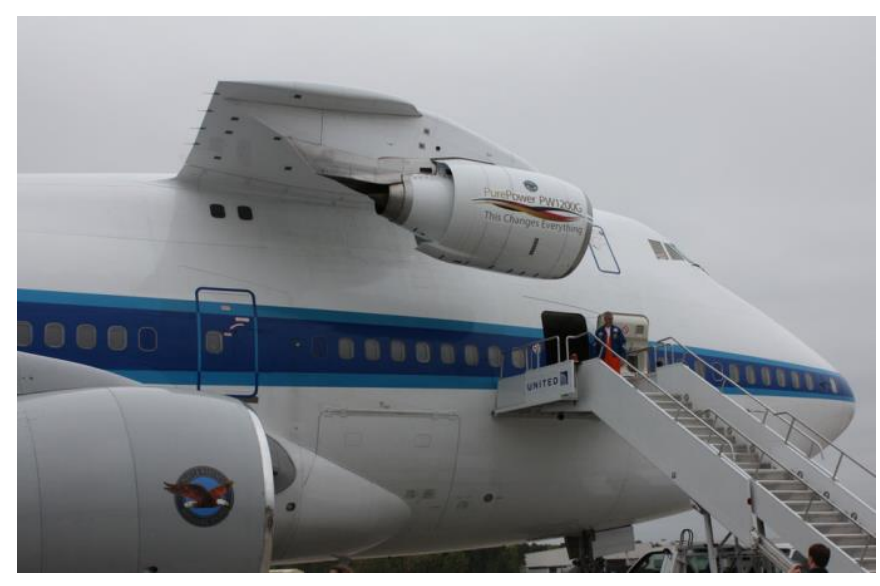

Figure 3 Flying test bed - Boeing 747-SP Chyba! Nenašiel sa žiaden zdroj odkazov.

The flying test bed can also have the engine installed in a special location. For example, Pratt \& Whitney owns two Boeing 747-SP aircraft. The engine uder the test can be mounted on a special pylon 
in front of the aircraft behind the pilot's cabin (see Fig. 3) Chyba! Nenašiel sa žiaden zdroj odkazov..

\section{ENGINE TEST CYCLE}

Engine should be tested in accordance to its purpose. It realizes many typical flights during its life cycle. Definition of a typical flight is the basis of an engine typical working cycle. It involves two important information. The first one is flight duration (number of flight hours) and the second one is number of low cycle fatigue cycles. The ground test sequence mimick typical mission simulation. An engine test sequence/cycle is repeated according to the needs related to engine life. The test run of the engine is a set of repeating sequences of regimes and transitions between them. As mentioned above, the sequence is constructed with a consideration to future use of the engine. One sequence represents the load of critical engine components during a typical flight of aircraft, in which the engine is to operate.

In the next list and a graph in Fig. 4 the components of AGTE test cycle for passenger aircraft can be seen. It represents standard flight of an airliner.

1. Engine starting, up to idle (duration 20s),

2. idle/ground idle (check of systems, aircraft taxiing to runway), (duration 80s),

3. acceleration,

4. maximum take-off (duration 10s),

5. maximum climbing (climb to flight level, duration 80s),

6. deceleration to cruise regime (duration 10s),

7. cruise (duration 160s) (until there is any change of flight level),

8. flight idle (descend, approach and landing), (duration 40s),

9. reversing (braking after landing with redirected thrust by using the maximum engine speed), (duration 20s),

10. ground idle (taxiing and waiting at the airport), (duration 100s).

11. shut-down the engine (duration 20s).

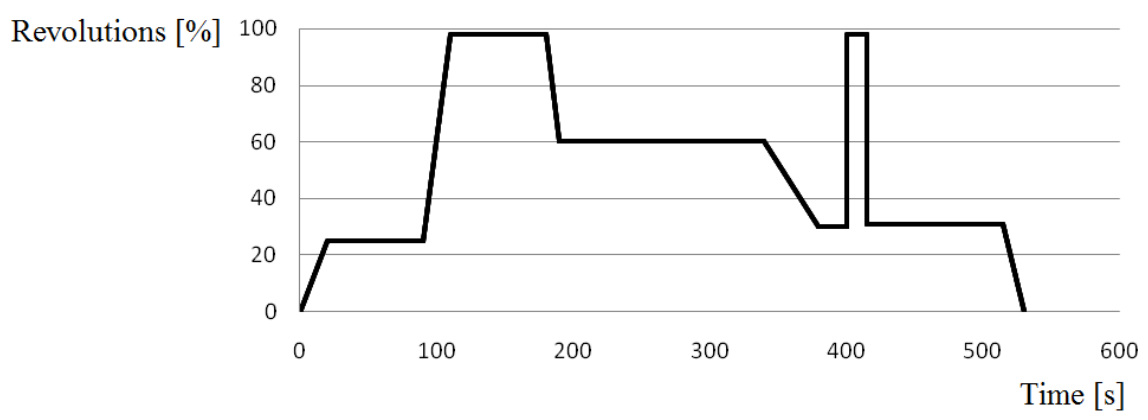

Figure 3 Simplified engine test cycle

The cycle can be repeated without shutting down the engine. There can be different endurance time at any regime, to control the thermal load of engine materials. The testing basically cannot be as long as the real life of the engine, so testing engineers look for ways to replace lower stress regimes with higher stress regimes, but with shorter duration. The resulting accumulation of fatigue damage should be the same as at the real lower regimes.

With modular design of AGTE the different allowable number of fatigue cycles can be achieved for different engine modules (fan, compressor, high pressure turbine wheel, etc.) [5].

The main causes of the fatigue damage are fast changes of material temperature and consequent mechanical stress in the material. Therefore, the life duration tests focus on the so-called engine cycling. The term means fast and frequent changes of regimes, aimed on fatigue development. 
The individual cycles vary depending on the type of aircraft / engine, the choice of designer and on other factors and considerations.

\section{CONCLUSION}

An AGTE certification has several goals. There is a need of different test cycles proposal for different properties tested. Long duration runs with minimal changes of regimes suit for overall flight hours proving. They cannot be used for VTOL aircraft engine that is used also for flight stabilization [6]. "Engine cycling" testing cycle suits for investigation of fatigue resistance. The engine test cycles have to be adapted to the intended use of the aircraft. Operational parameters can be restricted according to testing results.

The testing processes may vary over the time, depending on engine purpose, design, material availability and use [7]. Reliability requirements may also be changed during the engine life. These circumstances must be recognized by a designer and an examiner, when the engine undergo overhaul.

The results of research introduced in this work were reached thanks to experiences of testing engineers. A design of an engine test cycle depends on assumed engine use. The number of cycles is not specified in this work, because it depends on planned engine life.

\section{References}

[1] Linhart, Z. Konstrukce leteckých motorů IV (Aircraft Engine Design IV), Brno: Vojenská akademie Antonína Zápotockého. 1982. 74 p.

[2] Ballough, J. Correlation, operation, design, and modification of turbofan/jet engine test cells, USA: U.S. Department of Transportation FAA, 2012. 45 p.

[3] Walsh, P. - Fletcher, P. Gas Turbine Performance, Bristol: Blackwell Publishing, 2004. 646 p., ISBN 0-632-06434-X (alk. paper)

[4] Donner, R. Pratt \& Whitney's Flying Test Bed. Available at: https://www.aviationpros.com/ aircraft/commercial-airline/blog/10712153/pratt-whitneys-flying-test-bed

[5] Cernan, J., et al._Fatigue stress analysis of the DV-2 engine turbine disk, In: Aircraft Engineering and Aerospace Technology. - Great Britain: Emerald Group Publishing Year. 91, No. 4 (2019), s. 708-716 [online]. - ISSN 1748-8842

[6] Fábry, S. - Gašparovič, P. - Tulipán, P. Stability of a Hovering Coleoptere, In: New Trends in Aviation Development 2018: The 13. International Scientific Conference. - Danvers (USA): Insti-tute of Electrical and Electronics Engineers, 2018 p. 50-54. - ISBN 978-1-5386-7917-3

[7] Andoga, R.., \& et al. Intelligent Situational Control of Small Turbojet Engines. International Journal of Aerospace Engineering, vol. 2018, Article ID 8328792, 16 pages, 2018. Available at: https://doi.org/10.1155/2018/8328792.

[8] Rozenberg, R., et al. Civilné dopravné lietadlá 1. Košice: TU, 2012. 190 pp. ISBN 978-80-553$1389-4$.

[9] Rozenberg, R., et al. Civilné dopravné lietadlá 2. Košice: Multiprint, 2015. 163 p. ISBN 97880-89551-21-7.

[10] Rozenberg, R., et al. Civilné dopravné lietadlá 3: Turbovrtulové dopravné lietadlá. Košice: Technická univerzita v Košiciach, 2018. 237 p. ISBN 978-80-553-2950-5.

Received 09, 2019, accepted 12,2019

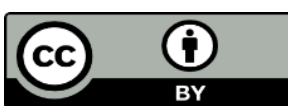

Article is licensed under a Creative Commons Attribution 4.0 International License 